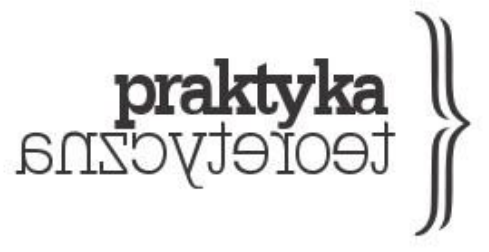

Praktyka Teoretyczna

Numer 4(26)/2017

ISSN 2081-8130

DOI: $10.14746 /$ prt.2017.4.13

www.praktykateoretyczna.pl

\title{
AGRARNE POCZĄTKI KAPITALIZMU
}

\author{
ELLEN MEIKSINS WOOD
}

PRZELOŻYŁ: ELIASZ ROBAKIEWICZ

\begin{abstract}
Abstrakt: Tekst przedstawia podstawowe założenia i tezy „marksizmu politycznego”. Autorka wykazuje, jak i dlaczego początki kapitalizmu należy wiązać w pierwszej kolejności z wsią i rolnictwem, a dopiero w drugiej z miastem i handlem. Podporządkowanie procesów produkcji żywności imperatywom kapitalizmu stanowi o rewolucjonizującym charakterze kapitalizmu, gdyż przekształceniu ulegaja $\mathrm{w}$ ten sposób procesy odpowiedzialne za samą reprodukcję społeczeństwa, a nie jedynie dystrybucji lub redystrybucji nadwyżek.
\end{abstract}

Słowa kluczowe: kapitalizm, Meiksins Wood, marksizm polityczny, historia, rynek 
Wiązanie kapitalizmu z życiem miejskim jest jedną z najgłębiej zakorzenionych cech zachodniej kultury¹. Przyjmuje się, że kapitalizm zrodził się i dojrzewał w mieście. Co więcej, sugeruje się, iż każde miasto - z typowo miejskimi praktykami wymiany i handlu - ma z samej swej istoty, od samego poczattku potencjalnie kapitalistyczny charakter i jedynie zewnętrzne przeszkody stają każdej miejskiej cywilizacji na drodze do wydania z siebie kapitalizmu. Niewłaściwa religia, niewłaściwa postać państwa lub jakiekolwiek formy ideologiczne, polityczne czy kulturowe, które wiążą ręce klas miejskich - to one miały od niepamiętnych czasów uniemożliwiać kapitalizmowi rozwój w dowolnym miejscu, a przynajmniej odkąd technologia pozwoliła mu na wytwarzanie odpowiednich nadwyżek.

Zgodnie z tym poglądem rozwój kapitalizmu na Zachodzie wywodzi się ze szczególnej autonomii miast i typowych dla nich klas: mieszczan bądź burżuazji. Innymi słowy, powodem pojawienia się kapitalizmu na Zachodzie było nie tyle to, co już tam istniało, ale raczej to, czego brakowało, mianowicie brak ograniczeń dla miejskiej działalności gospodarczej. W tych warunkach, wystarczyła mniej lub bardziej naturalna ekspansja samego handlu, by spowodować rozwój kapitalizmu aż do jego dojrzałej postaci. Wszystko, co było potrzebne, to odpowiedni wzrost ilościowy, który zaistniał niemal nieuchronnie wraz z upływem czasu (w niektórych przypadkach pomogła mu oczywiście, choć sama z siebie go nie wydała, etyka protestancka).

Można sformułować bardzo wiele zarzutów wobec poglądów o naturalnym związku pomiędzy miastami a kapitalizmem, np. że prowadzą one do naturalizacji kapitalizmu, jednocześnie ukrywając jego specyfikę jako historycznie określonej formy społecznej, która ma swój początek i (bez wątpienia) koniec. Tendencji do identyfikowania kapitalizmu z miastami i uprawianym w nich handlem towarzyszy zazwyczaj skłonność do przedstawiania kapitalizmu jako systemu będącego mniej lub bardziej naturalną konsekwencja praktyk „starych jak sam świat" czy po prostu ludzkiej natury. Zgodnie ze słowami Adama Smitha jest to naturalna skłonność do „wymiany, handlu i zamiany”.

Być może najbardziej produktywną korektą tych założeń i ich ideologicznych implikacji jest uznanie, że kapitalizm, wraz z wszystkimi jego specyficznymi dążeniami do akumulacji i maksymalizacji zysków, zrodził się nie w mieście, ale na wsi, w precyzyjnie określonym miejscu i to bardzo późno w historii ludzkości. Narodziny kapitalizmu nie wymagały jedynie prostego rozszerzenia czy zwiększenia handlu i wymiany, lecz całkowitej transformacji najbardziej podstawowych ludzkich relacji i praktyk, zerwania wielowiekowych wzorców interakcji człowieka z przyrodą w procesie wytwarzania najbardziej podstawowych względem potrzeb życiowych wyrobów. Jeśli tendencja do identyfikowania kapitalizmu z miastami wiąże się $z$ tendencja do zaciemniania specyfiki kapitalizmu, to jednym z najlepszych sposobów zrozumienia tej specyfiki jest rozważenie jego agrarnego pochodzenia.

\footnotetext{
1 Niniejszy artykuł ukazal się pierwotnie w Monthly Review 1998, 50 (3) (https://monthlyreview.org/ 1998/07/01/the-agrarian-origins-of-capitalism/). Meiksins Wood była współwydawczynią oraz stale publikującą autorką tego pisma. Prawa do jego polskiego tłumaczenia zostały nieodpłatnie udostępnione redakcji Praktylki Teoretycznej dzięki uprzejmości redaktorek Monthly Review (przyp. tłum.).
} 


\section{Czym był „agrarny kapitalizm”?}

Przez tysiąclecia ludzie zaspokajali swoje materialne potrzeby, pracując na roli. I zapewne tak długo, jak zajmowali się rolnictwem, dzielili się na klasy - na tych, którzy pracowali na roli oraz tych, którzy zawłaszczali pracę innych. Ten podział na zawłaszczających i wytwórców przybierał różne formy w różnych okresach i miejscach, lecz ich cechą wspólną było to, że bezpośrednimi wytwórcami byli zazwyczaj chłopi. Owi chłopscy wytwórcy pozostawali w posiadaniu środków produkcji, w szczególności samej ziemi. Tak jak we wszystkich społeczeństwach przedkapitalistycznych producenci ci mieli bezpośredni dostęp do środków własnej reprodukcji. Oznaczało to, że kiedy ich dodatkowa praca była przywłaszczana przez wyzyskiwaczy, odbywało się to poprzez środki, które Marks nazwał „pozaekonomicznymi”, czyli za pomoca bezpośredniego przymusu stosowanego przez właścicieli ziemskich i/lub państwo, które posiadało największą władzę w postaci władzy sędziowskiej i politycznej, jak również uprzywilejowany dostęp do wojska.

Oto właśnie najbardziej podstawowa różnica pomiędzy wszystkimi przedkapitalistycznymi społeczeństwami a kapitalizmem. Nie ma to nic wspólnego z tym, czy produkcja ma charakter miejski, czy agrarny. Kluczowe znaczenie mają natomiast szczególne stosunki własności między producentami a wywłaszczycielami, czy to w przemyśle, czy w rolnictwie. Wyłącznie w kapitalizmie dominujący sposób zawłaszczania nadwyżek opiera się na wywłaszczeniu bezpośrednich producentów, których praca dodatkowa jest zawłaszczona czysto „ekonomicznymi” środkami. Ponieważ bezpośredni wytwórcy w ramach w pełni rozwiniętego kapitalizmu są wyzuci z własności, a jedyną formą dostępu do środków produkcji i jednocześnie do środków ich własnej reprodukcji, a nawet do środków własnej pracy jest sprzedaż swej siły roboczej w zamian za płacę, kapitaliści moga przywłaszczać sobie pracę dodatkowa pracowników bez odwoływania się do bezpośredniego przymusu.

Ten szczególny stosunek między producentami a właścicielami jest oczywiście zapośredniczony przez „rynek”. Rynki różnego typu istniały w całej znanej nam historii i bez waţpienia jeszcze wcześniej, jako że ludzie wymieniali i sprzedawali swoje nadwyżki na wiele różnych sposobów i w wielu różnych celach. Niemniej jednak rynek w kapitalizmie ma bardzo specyficzny charakter i pełni zupełnie wyjątkową historycznie funkcję. Praktycznie wszystko w społeczeństwie kapitalistycznym jest towarem wytworzonym w celu sprzedaży na rynku. Co więcej, zarówno kapitał, jak i siła robocza są całkowicie zależne od rynku jako najbardziej podstawowego warunku własnej reprodukcji. Tak jak robotnicy zależą od rynku, by sprzedawać swoją siłę roboczą jako towar, tak samo też od rynku zależni są kapitaliści, którzy muszą kupować siłę roboczą oraz środki produkcji, a także zrealizować swoje zyski, sprzedając towary lub usługi wytwarzane przez pracowników. Ta zależność nadaje rynkowi ową zupełnie wyjątkową rolę w społeczeństwach kapitalistycznych, czyniąc zeń nie tylko prosty mechanizm 
wymiany czy dystrybucji, ale główny wyznacznik i regulator reprodukcji społecznej. Pojawienie się rynku jako kluczowego czynnika determinującego sposób reprodukcji społecznej zakładało, że przeniknie od do procesu wytwarzania najbardziej podstawowego dobra - żywności.

Ten unikalny system zależności rynkowej pociąga za sobą bardzo charakterystyczne „prawa ruchu”, specyficzne systemowe wymagania i przymusy, którymi nie cechuje się żaden inny sposób produkcji: imperatywy konkurencji, akumulacji i maksymalizacji zysku. Te imperatywy sprawiają, że kapitalizm może, a de facto musi nieustannie rozszerzać się na sposób i skalę niespotykane $\mathrm{w}$ innych formach społecznych, nieustannie gromadząc, poszukując nowych rynków, narzucając swoje imperatywy nowym obszarom i nowym sferom życia, zarówno istotom ludzkim, jak i środowisku naturalnemu.

Kiedy zrozumiemy, jak bardzo wyjątkowe są te stosunki i procesy społeczne, jak różne od obecnych w innych formach społecznych, które dominowały przez większość historii ludzkości, stanie się zupełnie jasne, że potrzebne jest bardziej kompleksowe wyjaśnienie pojawienia się tej wyjątkowej formy społecznej niż sprowadzenie jej do mocno watpliwego założenia, że istniała ona niejako już zawsze, „,w zarodku”, który musiał jedynie uwolnić się od nienaturalnych barier dla swojego rozwoju. W związku z tym kwestię pochodzenia kapitalizmu można sformułować w następujący sposób: biorąc pod uwagę, że wytwórcy przez całe tysiąclecia przed nadejściem kapitalizmu byli wykorzystywani przez wyzyskiwaczy na niekapitalistyczne sposoby, a także, że rynki istniały również niemal wszędzie „od niepamiętnych czasów”, jak doszło do tego, że zarówno wytwórcy, jak i wywłaszczyciele oraz relacje między nimi stały się tak bardzo zależne od rynku?

Długie i złożone procesy historyczne, które ostatecznie doprowadziły do stanu zależności rynkowej, można rzecz jasna prześledzić, cofając się w nieskończoność. Możemy ułatwić sobie jednak zadanie przez zidentyfikowanie miejsca i czasu, w którym po raz pierwszy nowa dynamika społeczna, będąca pochodną rynkowego uzależnienia głównych aktorów gospodarczych, stała się wyraźnie dostrzegalna. Będziemy dzięki temu w stanie przebadać specyficzne warunki określające tę wyjątkową sytuację.

Jeszcze w siedemnastym wieku, a nawet znacznie później, większość świata, nie wyłączając Europy, była wolna od nakreślonych tutaj rynkowych imperatywów. Z pewnością istniał już rozległy system handlu rozciagający się na cały glob. Nigdzie jednak, ani w wielkich metropoliach handlowych Europy, ani w rozbudowanych sieciach handlu świata muzułmańskiego czy Azji, nie istniała działalność gospodarcza, zwłaszcza w sferze produkcji, napędzana przez imperatywy konkurencji i akumulacji. Dominująca zasada handlu na całym świecie był „zysk ze sprzedaży” [profit on alienation] bądź „kupowanie tanio i sprzedawanie drogo" - zazwyczaj kupowanie tanio na jednym rynku i sprzedawanie drogo na innym.

Handel międzynarodowy polegał zasadniczo na transporcie dóbr, kupcy nabywali towary w jednym miejscu, by sprzedać je z zyskiem w innym. Nawet we Francji, silnym i w dużym 
stopniu ujednoliconym królestwie europejskim, dominowały dalej właśnie te zasady handlu niekapitalistycznego. Nie istniał jednolity i zunifikowany rynek, taki na którym ludzie osiagaliby zyski nie kupując tanio i sprzedając drogo, nie przewożąc towarów z jednego rynku na drugi, ale przez produkcję opartą na optymalizacji kosztów w bezpośredniej konkurencji z innymi producentami na tym samym rynku.

Handel nadal był nastawiony przeważnie na dobra luksusowe, a przynajmniej na towary przeznaczone dla zamożniejszych gospodarstw domowych lub odpowiadających na potrzeby i wzorce konsumpcji klas dominujących. Nie było masowego rynku tanich produktów codziennego użytku. Zwykle chłopi produkowali na swoje potrzeby nie tylko żywność, ale także inne dobra codziennego użytku jak choćby odzież. Mogli oczywiście sprzedać swoje nadwyżki na lokalnym rynku, gdzie mogły one zostać wymienione na inne towary, które nie były produkowane w domu. Same te produkty rolne mogły w konsekwencji być nawet sprzedawane na rynkach położonych dalej. Jednak zasady handlu były zasadniczo takie same jak w przypadku towarów specjalnie wytworzonych na tego typu rynki.

Te niekapitalistyczne zasady handlu współistniały z niekapitalistycznymi sposobami wyzysku. Na przykład w Europie Zachodniej, nawet tam, gdzie realnie zniesione zostały stosunki feudalne, nadal dominowały inne formy „pozaekonomicznego” wyzysku. Na przykład we Francji, gdzie chłopi wciąż stanowili zdecydowana większość ludności i pozostawali w posiadaniu większości ziemi, stanowiska urzędnicze w scentralizowanym aparacie państwowym służyły wielu członkom klas dominujących jako źródło ekonomicznych zasobów i sposób wydobywania pracy dodatkowej w formie podatków od chłopskich wytwórców. Nawet pobierający czynsz za dzierżawę ziemi właściciele ziemscy, powiększając swoje bogactwo, polegali zazwyczaj na różnych formach uprawnień i przywilejów pozaekonomicznych.

Chłopi mieli dostęp do środków produkcji (ziemi) bez konieczności oferowania swojej siły roboczej jako towaru na rynku. Posiadacze ziemscy i urzędnicy państwowi, przy pomocy różnych „pozaekonomicznych” uprawnień i przywilejów, zawłaszczali pracę dodatkową chłopów bezpośrednio w formie czynszu lub podatków. Innymi słowy, podczas gdy każdy mógł kupować i sprzedawać wszelakiego rodzaju towary na rynku, ani chłopi jako właściciele ziemi (główni producenci), ani właściciele ziemscy i posiadacze urzędów, którzy zawłaszczali to, co inni produkowali, nie byli zależni bezpośrednio od rynku pod względem warunków własnej reprodukcji, a stosunki między nimi nie były zapośredniczone przez rynek.

Istniał jednak jeden znaczący wyjątek od tej ogólnej zasady. Anglia już w szesnastym wieku rozwijała się w zupełnie nowym kierunku. Chociaż istniały inne, stosunkowo silne monarchiczne państwa, mniej lub bardziej zjednoczone pod berłem monarchii (jak Hiszpania czy Francja), pod względem centralizacji władzy żadne z nich nie dorównywało Anglii (i nacisk kładę tu na Anglię, nie na inne części „Wysp Brytyjskich”). W szesnastym wieku Anglia - już 
od jedenastego wieku bardziej zjednoczona niż większość królestw dzięki osiedleniu się na wyspie normandzkiej klasy panującej jako stosunkowo zwartej siły militarnej i politycznej podjęła liczne działania w celu przezwyciężenia rozdrobnienia państwa oraz „rozdrobnionej suwerenności" odziedziczonej po feudalizmie. Władza suwerenna panów feudalnych, organy miejskie i inne podmioty korporacyjne w innych państwach europejskich były w Anglii w dużo większym stopniu skoncentrowane we władzy centralnej. Taki stan rzeczy stanowił jaskrawe przeciwieństwo kondycji innych państw europejskich, w których nawet potężne monarchie przez długi czas trwały w burzliwym związku z innymi post-feudalnymi siłami wojskowymi, rozdrobnionymi systemami prawnymi i przywilejami korporacyjnymi, których posiadacze naciskali na zachowanie autonomii wobec centralizującej potęgi państwa.

Wyróżniająca polityczna centralizacja państwa angielskiego miała swe materialne podstawy i przesłanki. Po pierwsze, już w szesnastym wieku Anglia posiadała imponującą sieć dróg i transportu wodnego, które jednoczyły kraj w stopniu niezwykłym dla tego okresu. Londyn, stając się nieproporcjonalnie duży w stosunku do innych miast angielskich oraz do całej populacji Anglii (i ostatecznie urastając do rangi największego miasta w Europie), stał się osią rozwijającego się rynku krajowego.

Materialna podstawą, na której opierała się ta wschodząca gospodarka narodowa, było wyjątkowe pod kilkoma względami rolnictwo. Angielska klasa panująca wyróżniała się w dwóch głównych i wzajemnie powiązanych aspektach. Z jednej strony jako integralna część coraz bardziej scentralizowanego państwa w sojuszu z dążącą do centralizacji monarchią klasa ta nie posiadała suwerennej „pozaekonomicznej” władzy (w samym stopniu jak jej odpowiedniki na kontynencie), na której mogły polegać inne klasy rządzące, mając na celu wydobywanie pracy dodatkowej od bezpośrednich wytwórców. Z drugiej strony ziemia w Anglii od dawna już była niezwykle skoncentrowana, a wielcy właściciele posiadali jej znacząca część. Ten typ skoncentrowanej własności ziemskiej pozwalał angielskim posiadaczom wykorzystać swoja własność w nowy i specyficzny sposób. Brak „pozaekonomicznej” władzy pozwalającej na zawłaszczanie nadwyżek rekompensowali sobie $z$ nawiązką coraz większą władzą „ekonomiczną".

Ten charakterystyczny typ własności niósł ze sobą poważne konsekwencje. Z jednej strony koncentracja angielskich posiadłości ziemskich oznaczała, że wyjątkowo duża część pracy rolnej była wykonywana nie przez chłopów-właścicieli, ale przez dzierżawców (słowo farmer, nawiasem mówiąc, dosłownie oznacza dżierżawce - użycie sugerowane przez zwroty znane dzisiaj takie jak farming out [sformułowanie oznaczające wysługiwanie się cudzą praca]).Taki stan został osiagnnięty jeszcze przed falami wywłaszczeń, zwłaszcza w wiekach szesnastym i osiemnastym określanych tradycyjnie mianem ,grodzenia” (o czym więcej za moment). Zupełnie inaczej wyglądało to na przykład we Francji, gdzie większa część ziemi pozostawała i jeszcze długo miała pozostać w rękach chłopów. 
Z drugiej strony stosunkowo słaba „pozaekonomiczna” władza właścicieli ziemskich sprawiała, że w znacznie mniejszym stopniu polegali oni na swoich zdolnościach do wyciskania czynszów z dzierżawców w sposób bezpośredni (za pomocą środków przymusu, społecznie usankcjonowanej przemocy), a raczej polegając na samej wydajności pracy najemców. Właściciele mieli zatem silną motywację, aby zachęcać i, jeżeli było to możliwe, zmuszać swych dzierżawców do szukania sposobów zwiększania wydajności. Pod tym względem różnili się oni zasadniczo od arystokratycznej klasy rentierów, którzy historycznie osiagali swoje bogactwo poprzez wyciskanie nadwyżek z chłopów za pomocą zwykłego przymusu, koncentrując się na zwiększaniu swojej zdolności do pozyskiwania nadwyżek nie poprzez wzmaganie produktywności bezpośrednich producentów, lecz poprzez ulepszania własnych zdolności do wywierania przymusu - tak militarnego, prawnego, jak i politycznego.

Jeśli chodzi o samych dzierżawców byli poddawani nie tylko rosnącej presji ze strony właścicieli ziemskich, ale i rynkowych imperatywów, które zmuszały ich do zwiększania produktywności. Angielska forma dzierżawy miała wiele wariantów, istniało wiele różnic regionalnych, jednak rosnący odsetek stawał się uzależniony od czynszów o „ekonomicznym charakterze", których forma i wysokość nie była ustalona jakimś wzorcem prawnym lub zwyczajowym, lecz określana przez warunki rynkowe. Już we wczesnym okresie nowożytnym wiele umów najmu określanych tradycyjnie (przez prawo zwyczajowe) zostało skutecznie przeistoczonych w taką ,ekonomiczną” formę dzierżawy.

W efekcie oddziaływania tego systemu stosunków własności wielu producentów rolnych (w tym świetnie prosperujących „yeomenów”2) było zależnych od rynku w bardziej fundamentalny sposób niż konieczność sprzedaży produktów na rynku. Ich dostęp do samej ziemi, do ich środków produkcji był rynkowo uwarunkowany: powstał rynek dzierżaw, na którym konkurować musiała poszerzająca się grupa bezrolnych wytwórców. Na rynku tym zabezpieczenie możności dzierżawy zależało od zdolności do płacenia bieżącego czynszu, a niekonkurencyjne gospodarowanie prowadziło w prosty sposób do całkowitej utraty ziemi. Aby sprostać „ekonomicznym” czynszom w sytuacji, w której inni potencjalni najemcy konkurowali o te same umowy najmu, dzierżawcy byli zmuszeni do produkowania w sposób efektywny pod względów kosztów. W przeciwnym razie groziło im wywłaszczenie.

W warunkach, w których konkurencyjne normy wydajności były określane przez producentów natychmiastowo i bezpośrednio w reakcji na presje rynku, plajta groziła nawet tym wytwórcom, którzy cieszyli się pewnego rodzaju zwyczajową dzierżawą zapewniającą im większe bezpieczeństwo. To samo w coraz większym stopniu tyczyło się nawet właścicieli ziemskich uprawiających swą ziemię. W tym konkurencyjnym środowisku wydajni rolnicy cieszyli się powodzeniem, a ich gospodarstwa miały spore szanse wzrostu, podczas gdy mniej

\footnotetext{
${ }^{2}$ Bogaci posiadacze chłopscy (przyp. tłum.).
} 
konkurencyjni wytwórcy znajdywali się coraz bliżej sytuacji bez wyjścia, by ostatecznie zasilić szeregi rosnącej klasy pozbawionej jakiejkolwiek własności

We wszystkich podanych przypadkach efektem oddziaływania imperatywów rynkowych było nasilenie się wyzysku w celu zwiększenia produktywności - czy to przez wykorzystywanie pracy innych osób, czy też samowyzysk rolników i ich rodzin. Ten wzorzec był także reprodukowany w koloniach, a nawet w Ameryce po uzyskaniu niepodległości, gdzie drobni, niezależni rolnicy, którzy mieli stanowić kręgosłup wolnej republiki, zostali od samego początku postawieni przed ciężkim i nieuniknionym wyborem agrarnego kapitalizmu: w najlepszym wypadku intensywnego samowyzysku, a w najgorszym wywłaszczenia i wysiedlenia spowodowanego przez większe, bardziej produktywne przedsiębiorstwa.

\section{Wyłonienie się własności kapitalistycznej}

Tak więc już w szesnastym wieku angielskie rolnictwo cechował unikalny splot warunków. Dotyczyło to przynajmniej niektórych regionów, które jednak stopniowo wyznaczały kierunek ekonomicznego rozwoju całej gospodarki. W rezultacie powstał sektor rolny o większej produktywności niż jakikolwiek inny w historii. Zarówno właściciele ziemscy, jak i dzierżawcy stawali się kompletnie zaabsorbowani tym, co nazywali „ulepszeniem” czy „postępem” [improvement], czyli poprawą produktywności ziemi, mającą na celu maksymalizację zysku.

Warto chwilę zatrzymać się nad tą koncepcją „ulepszania”, gdyż mówi nam ona wiele o angielskim rolnictwie i rozwoju kapitalizmu. Sformułowanie „ulepszać” [to improve] w swoim oryginalnym znaczeniu nie oznaczało po prostu „czynić lepszym” w sensie ogólnym, ale dosłownie robić coś dla zysku pieniężnego, a w szczególności uprawiać ziemię dla zysku (w oparciu o starofrancuskie „dla” [en] i „zysk” [pros] lub w formie obocznej preu). Do siedemnastego wieku słowo „polepszacz” [improver] zostało mocno utrwalone w języku i odnosiło się do kogoś, kto czynił gospodarowanie produktywnym i zyskownym, szczególnie przez grodzenie lub pozyskiwanie nieużytków. „Ulepszanie” rolnictwa było już wtedy dobrze ugruntowana praktyka, a w osiemnastym wieku, czyli złotym wieku kapitalizmu agrarnego, to „ulepszenie”, zarówno jako słowo i czynność, rozwinęło się w pełni.

Jednocześnie słowo to stopniowo nabrało ogólniejszego znaczenia, tego, które znamy dzisiaj (warto byłoby pomyśleć o wnioskach, jakie nasuwają się na temat kultury, w której sformułowanie „uczynić lepszym” jest zakorzenione w sformułowaniu „uczynić zyskownym”). Z czasem ostatecznie utraciło ono swoją dawną specyfikę, nawet w kontekście rolnictwa. W ten sposób na przykład niektórzy radykalni myśliciele dziewiętnastego wieku używali słowa „ulepszać” w sensie naukowo wspomaganego rolnictwa, bez jego konotacji wobec komercyjnego zysku. Niemniej jednak we wczesnym okresie nowożytnym konotacja słowa 
„ulepszanie” w rolnictwie zawierała nierozerwalny związek produktywności i zysku - związek, który dobrze podsumowuje ideologię wschodzącego agrarnego kapitalizmu.

W siedemnastym wieku pojawiła się cała nowa gałąź literatury określającej z niespotykana dotąd szczegółowością techniki, a także korzyści płynące z „ulepszania”. „Ulepszanie” było również jednym z zajęć Towarzystwa Królewskiego (The Royal Society), które zrzeszało najwybitniejszych naukowców Anglii (jego członkami byli Isaac Newton i Robert Boyle) oraz niektórych, najbardziej postępowych przedstawicieli angielskich klas rządzących -vide żywo zainteresowani ulepszeniami w rolnictwie filozof John Locke i jego mentor, hrabia Shaftesbury.

Ulepszenia te nie zależały w pierwszej kolejności od jakichkolwiek znaczących innowacji technologicznych, chociaż używano nowego sprzętu takiego jak pług z kołem. Ogólnie rzecz biorąc, były to raczej innowacje w kwestii technik uprawy roli, na przykład uprawa „zmienna” czy typu „góra i dół” polegająca na naprzemiennej uprawie z okresami odłogowania, płodozmianem, odwadnianiem bagien i pól uprawnych itd.

„Ulepszanie” oznaczało jednak coś więcej niż nowe metody i techniki rolnicze. W bardziej fundamentalnym sensie oznaczało także nowe formy i koncepcje własności. Dla przedsiębiorczego posiadacza ziemi i jego dobrze prosperującego, kapitalistycznego dzierżawcy „ulepszanie” rolnictwa docelowo wymagało systematycznego powiększania i koncentracji własności ziemskich. Wymagało także, być może nawet w większym stopniu, zniesienia starych zwyczajów i praktyk, które stały na przeszkodzie najbardziej produktywnemu użytkowaniu ziemi.

Społeczności wiejskie od niepamiętnych czasów stosują różne formy regulacji użytkowania ziemi w interesie społeczności wiejskiej. Ograniczają niektóre praktyki i przyznaja określone prawa nie po to, by zwiększyć bogactwo właścicieli ziemskich czy państw, lecz by zachować samą społeczność chłopską. Charakterystyczna dla nich jest raczej ochrona ziemi czy redystrybucja jej płodów w sposób podtrzymujacy określony wzorzec sprawiedliwości, a często także w celu zapewnienia wsparcia dla gospodarstw dotkniętych problemami. Nawet „prywatne” posiadanie własności jest zwykle uwarunkowane takimi zwyczajowymi praktykami, które pozwalaja nieposiadającym na pewne prawa do użytkowania „posiadanej” przez kogoś innego własności. W Anglii było wiele tego rodzaju praktyk i zwyczajów. Istniały ziemie wspólne, na których członkowie społeczności mogli wypasać bydło lub zbierać drewno na opał. Istniały także różne formy praw do użytkowania prywatnej ziemi, takie jak prawo do zbierania resztek po zbiorach w określonych porach roku.

Z punktu widzenia wprowadzających ulepszenia właścicieli ziemskich i kapitalistycznych rolników ziemia musiała zostać uwolniona od wszelkich przeszkód, by mogli oni produktywnie i zyskownie korzystać z własności. Między szesnastym a osiemnastym wiekiem narastała presja na zniesienie zwyczajowych praw, które wpływały na kapitalistyczną akumulację. Mogło to oznaczać różne kwestie: wiązać się z kwestionowaniem komunalnej własności wspólnych 
gruntów i wysunięciem żądania własności prywatnej; mogło także oznaczać wyeliminowanie różnych praw do użytkowania ziemi prywatnej; lub też mogło oznaczać kwestionowanie zwyczajowych umów najmu, które dawały wielu małorolnym chłopom prawo do posiadania bez jednoznacznego tytułu prawnego. We wszystkich tych przypadkach tradycyjne koncepcje własności musiały zostać zastąpione przez nową, kapitalistyczną własność - nie tylko „prywatną, ale także wyłączna, dosłownie wykluczająca inne osoby oraz w ogóle społeczność poprzez wyeliminowanie regulacji wiejskich oraz wprowadzenie restrykcji w użytkowaniu gruntów przez znoszenie zwyczajowych praw użytkowania itd.

Naciski, aby przekształcić naturę własności, przejawiały się na różne sposoby w teorii i praktyce. Wypływały w sprawach sądowych, w sporach dotyczących określonych praw własności, a także o kawałek wspólnego gruntu, jak też o ziemię prywatną, do której różni ludzie posiadali nachodzące na siebie prawa użytkowania. W takich przypadkach zwyczajowe praktyki i roszczenia nierzadko konfrontowały się bezpośrednio z zasadami „ulepszeń” sędziowie często uznawali racje „ulepszeń” za uzasadniona podstawę dla roszczeń przeciwko zwyczajowym prawom, które obowiązywały od niepamiętnych czasów.

Z czasem nowe koncepcje własności zaczęto formułować w bardziej systematyczny sposób, czego najlepszym przykładem jest Drugi traktat o rz̨qdzie Johna Locke’a. Rozdział 5 tej pracy jest klasycznym przykładem teorii własności opartej na zasadach „ulepszania”’. Własność jako „naturalne” prawo opiera się na tym, co Locke uważa za boski nakaz, by czynić ziemię produktywną i zyskowną, by ją ulepszać. Konwencjonalna interpretacja teorii własności Locke'a sugeruje, że to praca ustanawia podstawę prawa własności. Jednak uważna lektura rozdziału 5 poświęconego właśnie tematowi własności ukazuje jasno, że to, co tak naprawdę stanowi sedno sprawy, to nie praca jako taka, ale produktywne i zyskowne wykorzystanie własności, jej ulepszenie. Przedsiębiorczy, skoncentrowany na specyficznie rozumianym „ulepszaniu” ziemi właściciel ziemski ustanawia swoje prawo do własności nie poprzez własna, bezpośrednią pracę, ale przez produktywne wykorzystywanie swojej ziemi i pracy innych ludzi. Nieulepszona ziemia, czyli taka, której nie uczyniono produktywną i zyskowna (jak na przykład ziemie rdzennych mieszkańców obu Ameryk), jest „marnotrawiona” i jest prawem, a nawet obowiązkiem ,ulepszaczy”, by ją zająć.

Ta sama etyka ulepszania mogłaby być wykorzystana do usprawiedliwienia pewnych form wywłaszczenia nie tylko w koloniach, ale i w samej Anglii. To prowadzi nas do najsłynniejszej formy zredefiniowania praw własności: grodzeń. Są one często uznawane za zwykłą prywatyzację przez ogrodzenie wspólnej ziemi lub „otwartych pól” charakterystycznych dla części wsi angielskiej. Co ważniejsze, grodzenie oznaczało w szczególności zanikanie wspólnotowych i zwyczajowych praw użytkowania (z udziałem fizycznego ogradzania ziemi

\footnotetext{
${ }^{3}$ Por. Locke 2015, 269-285 (przyp. tłum.).
} 
lub bez niego), od których zależała możność zdobycia podstawowych środków do życia dla wielu ludzi.

Pierwsza fala grodzeń na dużą skalę miała miejsce w szesnastym wieku, kiedy to wielcy właściciele ziemscy starali się wypędzić zwykłych ludzi [commoners] z terenów, które można było wykorzystać jako pastwiska dla coraz bardziej lukratywnej hodowli owiec. Ówcześni komentatorzy uznawali, że to właśnie grodzenie bardziej niż jakikolwiek inny czynnik odpowiedzialne było za rosnąca plagę włóczęgów, tych wydziedziczonych „ludzi bez pana”, którzy wędrowali po wsiach i zagrażali porządkowi społecznemu. Najsławniejszy z tych komentatorów, Thomas More, choć sam dokonywał grodzeń, opisywał tę praktykę jako sytuację, w której „owce pożerają ludzi”. Owi krytycy społeczni, podobnie jak wielu późniejszych historyków, przeceniali efekty samych grodzeń kosztem innych czynników prowadzących do przemiany stosunków własności w Anglii. Grodzenia pozostały jednak najbardziej wyrazistym efektem tego nieustającego procesu, który zmienił nie tylko angielską wieś, lecz również świat - narodzin kapitalizmu.

Grodzenia stanowiły główne źródło konfliktów we wczesnonowożytnej Anglii, niezależnie czy prowadzono je dla chowu owiec, czy dla coraz bardziej opłacalnych upraw. Zamieszki powodowane grodzeniami powtarzały się przez szesnasty i siedemnasty wiek. Same grodzenia zaś uzewnętrzniły się jako jedna z najważniejszych krzywd znajdujących ujście w angielskiej wojnie domowej. We wcześniejszych fazach praktyki te były do pewnego stopnia ograniczane przez monarchię, choćby z powodu zagrożenia dla porządku publicznego. Kiedy klasom posiadaczy ziemskich udało się ukształtować władzę zgodnie z własnymi zapotrzebowaniami, proces ten został uwieńczony sukcesem w 1688 roku, w ramach tak zwanej „chwalebnej rewolucji”. Odtąd państwo więcej nie interweniowało, a w osiemnastym wieku pojawiła się nowa fala grodzeń. Były to tak zwane „grodzenia parlamentarne”. W tego typu grodzeniach usunięcie kłopotliwych praw własności, które ograniczały uprawnienia właścicieli do akumulacji kapitału, miało już swoje umocowanie w aktach parlamentu. Nic bardziej dosadnie nie świadczyło o triumfie agrarnego kapitalizmu.

Tak więc w Anglii, społeczeństwie, w którym bogactwo nadal pochodziło głównie z produkcji rolnej, reprodukcja obu głównych aktorów gospodarczych w sektorze rolniczym, bezpośrednich producentów i tych zawłaszczających ich nadwyżki, była co najmniej od szesnastego wieku coraz bardziej uzależniona od praktyk kapitalistycznych: maksymalizacji wartości wymiennej przez obniżanie kosztów i poprawę wydajności poprzez specjalizację, akumulację i innowacje.

Ten sposób zaspokojenia podstawowych potrzeb materialnych społeczeństwa angielskiego niósł ze sobą zupełnie nową dynamikę samonapędzającego się wzrostu, to znaczy proces akumulacji i ekspansji bardzo odmienny od „odwiecznych” cyklicznych wzorców materialnego funkcjonowania innych społeczeństw. Towarzyszyły mu również typowe dla 
późniejszego kapitalizmu procesy wywłaszczenia i powstawania mas nieposiadających żadnej własności. W tym sensie możemy mówić o „agrarnym kapitalizmie” we wczesnonowożytnej Anglii.

\section{Czy kapitalizm agrarny naprawdę był kapitalistyczny?}

Musimy zatrzymać się w tym miejscu, aby podkreślić dwie główne kwestie. Po pierwsze, to nie kupcy i nie producenci napędzali ten proces. Transformacja społecznych stosunków własności była mocno zakorzeniona w samej wsi, transformacja angielskiego handlu i przemysłu była zaś bardziej skutkiem niż przyczyną pojawienia się kapitalizmu. Kupcy mogliby doskonale funkcjonować w systemach niekapitalistycznych. Ich działalność kwitła na przykład w warunkach europejskiego feudalizmu, w którym czerpali oni korzyści nie tylko z autonomii miast, lecz również z rozdrobnienia rynków i możliwości prowadzenia transakcji pomiędzy jednym rynkiem a drugim.

Po drugie, co jest sprawą nawet bardziej zasadniczą, czytelnicy zauważyli pewnie, że termin „kapitalizm agrarny” był dotychczas używany bez odniesienia do pracy najemnej, którą wszyscy nauczyliśmy się uważać za istotę kapitalizmu. Wymaga to wyjaśnienia.

Trzeba po pierwsze stwierdzić, że wielu dzierżawców zatrudniało pracowników najemnych na taką skalę, że zidentyfikowana przez Marksa i innych „triada” - właścicieli ziemskich żyjących z kapitalistycznej renty gruntowej, kapitalistycznych dzierżawców żyjących z zysku oraz robotników żyjących z płacy - była przez wielu uważana za charakterystyczną cechę stosunków społecznych w agrarnej Anglii. Rzeczywiście, pogląd ten znajduje potwierdzenie, przynajmniej w odniesieniu do tych części kraju, zwłaszcza na wschodzie i południowym wschodzie, które charakteryzowały się wysoką produktywnością rolnictwa. Nowe formy presji ekonomicznej, pojawienie się konkurencji, która doprowadziła do wywłaszczenia mniej produktywnych rolników, były głównymi czynnikami polaryzacji populacji rolniczej na większych posiadaczy ziemskich i nieposiadających już własności robotników najemnych oraz wyłonienia się triady agrarnej. Oczywiście, presja na zwiększenie produktywności spowodowała odczuwalne zintensyfikowanie wyzysku pracowników najemnych.

Opisanie angielskiego kapitalizmu agrarnego za pomoca tej „triady” nie jest zatem pozbawione podstaw. Musimy jednak pamiętać, że presja konkurencji oraz nowe „prawa ruchu”, które były z nią związane, zależały w pierwszym rzędzie nie od istnienia mas proletariatu, ale zależnych od rynku dzierżawców-producentów. Pracownicy najemni, a zwłaszcza ci, którzy żyli wyłącznie z pracy najemnej jako podstawy utrzymania, a nie sezonowej pracy dodatkowej (taki rodzaj sezonowej i uzupełniającej pracy najemnej istniał od 
czasów starożytnych w społeczeństwach chłopskich), pozostawali wciąż w siedemnastowiecznej Anglii skromną mniejszością.

Ponadto presja konkurencji oddziaływała nie tylko na dzierżawców, którzy zatrudniali pracowników najemnych, lecz również na rolników, którzy sami byli bezpośrednimi producentami, zwykle wraz ze swoimi rodzinami, obywajacymi się bez pomocy pracy najemnej. Ludzie mogą być zależni od rynku - ich podstawowe warunki samoreprodukcji mogą zależeć od rynku nawet wtedy, gdy nie doszło do całkowitego wywłaszczenia. Uzależnienie od rynku wymaga jedynie utraty bezpośredniego dostępu (niezapośredniczonego przez rynek) do środków produkcji. Gdy imperatywy rynkowe głęboko przeniknęły tkankę społeczną, nawet bezpośrednia własność nie stanowiła już przed nimi ochrony. Zależność od rynku była przyczyna, a nie skutkiem masowej proletaryzacji.

Kwestia ta jest istotna $z$ wielu powodów, a problem ma daleko sięgające konsekwencje, o czym wspomnę nieco później. Na tym etapie rozważań istotne jest, że konkretna dynamika kapitalizmu była już rozwinięta w angielskim rolnictwie, zanim w ogóle rozpoczął się proces proletaryzacji siły roboczej. W rzeczywistości to właśnie ta dynamika była głównym czynnikiem doprowadzającym do proletaryzacji pracy w Anglii. Kluczowym czynnikiem było uzależnienie od rynku tak producentów, jak i wyzyskiwaczy, a także nowe imperatywy społeczne powstałe wskutek uzależnienia od rynku.

Niektórzy moga być nastawieni sceptycznie do przypisywania tej formacji społecznej określenia „kapitalistyczna”, albowiem kapitalizm jest dla nich z definicji oparty na wyzysku pracy najemnej. Choć sama niechęć jest usprawiedliwiona, powinno się jednak dostrzec, że bez względu jak nazwiemy ten okres, angielska gospodarka we wczesnej epoce nowożytnej napędzana przez formę organizacji (logikę) jej podstawowego sektora gospodarki, czyli rolnictwa działała już zgodnie z zasadami i „prawami ruchu”, które różniły się od tych panujących w każdym innym społeczeństwie od zarania dziejów. Owe „prawa ruchu” stanowiły warunki rozwoju dojrzałego kapitalizmu rzeczywiście opierającego się na wyzysku pracy najemnej, które nie zaistniały nigdzie indziej.

Jaki więc był wynik tych wszystkich przemian? Po pierwsze, angielska produkcja rolna stała się wyjątkowo wydajna. Pod koniec siedemnastego wieku, dla przykładu, produkcja ziarna i zbóż w Anglii wzrosła o tyle, że uczyniła kraj wiodącym eksporterem tych dóbr. Tak znaczące postępy w produkcji zostały osiagnięte przy użyciu stosunkowo nieznacznej ilościowo siły roboczej w rolnictwie. Na tym właśnie polegała wyjątkowość wydajności angielskiego rolnictwa.

Niektórzy historycy próbowali podważyć samą ideę kapitalizmu agrarnego, sugerując, że wydajność francuskiego rolnictwa w osiemnastym wieku była mniej więcej równa wydajności angielskiego. Co jednak tak na naprawdę mają oni na myśli? Czy to, że całkowita produkcja rolna w obu krajach była mniej więcej równa? Takie postawienie sprawy ukrywa fakt, że we 
Francji taki poziom produkcji został osiagnięty przez populację w zdecydowanej większości nadal składająca się z producentów chłopskich. Tymczasem w Anglii ten sam poziom całkowitej produkcji został osiagnięty przez znacznie mniejszą siłę roboczą, w społeczeństwie, gdzie następował spadek populacji wsi. Innymi słowy, chodzi tu nie o całkowita produkcję, ale o wydajność w sensie uzyskanego efektu z jednej jednostki pracy.

Fakty dotyczace demografii przemawiaja same za siebie. W latach od 1500 do 1700 Anglia, podobnie jak inne kraje europejskie, doświadczyła znacznego wzrostu liczby ludności. Wzrost populacji angielskiej był jednakże nietypowy w jednym istotnym aspekcie - odsetek ludności miejskiej zwiększył się ponad dwukrotnie (niektórzy historycy mówią wręcz o niemal jednej czwartej populacji już u schyłku siedemnastego wieku). Kontrast z przypadkiem Francji jest wymowny - tu populacja wsi pozostaje dość stabilna, stanowiąc wciąż około 85 do 90\% w okresie rewolucji francuskiej w 1789 roku. Do roku 1850, kiedy to populacja miejska Anglii i Walii wzrosła do około 40,8\% we Francji było to nadal jedynie 14,4\% (10,8\% w Niemczech).

Rolnictwo w Anglii już we wczesnym okresie nowożytnym było na tyle wydajne, że pozwalało na utrzymanie niezwykle dużej liczby osób niezajmujących się produkcją rolna. Fakt ten oczywiście świadczy nie tylko o użyciu szczególnie skutecznych technik rolnych. Jest on dobitnym wyrazem rewolucji w społecznych stosunkach własności. Podczas gdy Francja pozostała krajem produkcji chłopskiej, ziemia w Anglii była już skoncentrowana w rękach nielicznej grupy, zaś masa ludzi pozbawionych własności gwałtownie rosła. W czasie, gdy produkcja rolna we Francji nadal była zorganizowana w sposób dopuszczający tradycyjne praktyki chłopskie (nic podobnego do rozbudowanej angielskiej literatury „ulepszania” nie istniało w Francji, a społeczność wsi nadal narzucała produkcji swoje regulacje i restrykcje, oddziałując nawet na wielkich właścicieli ziemskich), angielskie rolnictwo było już dostosowane do imperatywów konkurencji i „ulepszenia”.

Warto dodać jeszcze jedną rzecz o charakterystycznej strukturze demograficznej Anglii. Niezwykły wzrost ludności miejskiej nie był równomierny wśród miast angielskich. W innych rejonach Europy typowym wzorem było rozproszenie populacji miejskiej pomiędzy kilkoma ważnymi miastami. Na przykład Lyon nie był znacznie mniejszy od Paryża. W Anglii zaś, Londyn stał się nieproporcjonalnie wielki - liczba jego mieszkańców wzrosła z około 60 tysięcy w 1520 do 575 tysięcy w 1700 roku, stając się w związku z tym największym miastem w Europie. W tym samym czasie inne miasta angielskie pozostawały znacznie mniejsze.

Z takiego wzoru wynika jednak znacznie więcej, niż jest to widoczne na pierwszy rzut oka. Świadczy on między innymi o przekształceniach społecznych stosunków własności w samym sercu kapitalizmu agrarnego. Na południu i południowym wschodzie nastapiło wywłaszczenie małych producentów, prowadząc do ich przemieszczenia i migracji. Docelowym miejscem stał się dla nich Londyn. Rozrost stolicy reprezentuje również rosnące ujednolicenie nie tylko państwa, ale także angielskiego rynku krajowego. Ogromne miasto stało 
się ośrodkiem angielskiego handlu - nie tylko jako główny punkt tranzytowy w handlu krajowym i międzynarodowym, ale także jako ogromny rynek dla dóbr konsumpcyjnych produkowanych w Anglii, co nie ograniczało się tylko do jego płodów rolnych. Innymi słowy, Londyn stał się na wiele sposobów symbolem powstającego w Anglii kapitalizmu, symbolem coraz bardziej zintegrowanego rynku (połączonego, zunifikowanego, konkurencyjnego) oraz produktywnego rolnictwa, a także wywłaszczonej ludności.

Długofalowe konsekwencje tego specyficznego wzorca powinny okazać się dość oczywiste. Chociaż nie jest to dogodny moment do badania powiązań między agrarnym kapitalizmem a późniejszym rozwojem Anglii, łącznie z pierwszą, ,industrializacją” gospodarki, niektóre rzeczy są oczywiste. Bez wydajnego sektora rolnego, który mógł utrzymywać znaczne populacje nierolniczej siły roboczej, pojawienie się pierwszego w świecie kapitalizmu przemysłowego byłoby mało prawdopodobne. Bez agrarnego kapitalizmu w Anglii nie byłoby żadnych wywłaszczonych mas, zmuszonych do sprzedawania swej siły roboczej za płacę. Bez owej wywłaszczonej nierolniczej siły roboczej nie byłoby żadnego masowego rynku tanich dóbr konsumpcyjnych codziennego użytku, takich jak żywność i tekstylia, który napędzał proces industrializacji Anglii. Wreszcie, bez rosnącego dobrobytu wraz z nowymi motywacjami dla ekspansji kolonialnej, odmiennymi od starych form pozyskiwania nowych terytoriów, brytyjski imperializm nie przyjąłby postaci motoru napędowego przemysłowego kapitalizmu. W konsekwencji (jest to bez watpienia punkt najbardziej kontrowersyjny) bez angielskiego kapitalizmu prawdopodobnie nie byłoby żadnego innego systemu kapitalistycznego. To presja konkurencji pochodząca z Anglii, zwłaszcza jej uprzemysłowionych części, zmuszała inne kraje do rozwoju gospodarczego w kapitalistycznym kierunku.

\section{Lekcje agrarnego kapitalizmu}

Czego dowiadujemy się dzięki temu o naturze kapitalizmu? Po pierwsze, możemy lepiej zrozumieć, dlaczego kapitalizm nie jest „naturalnym” oraz, w efekcie, nieuniknionym wynikiem ludzkiej natury czy też „prastarych praktyk społecznych” takich jak „wymiana, handel i zamiana". Jest on późnym i geograficznie określonym efektem bardzo specyficznych warunków historycznych. Ekspansywny pęd kapitalizmu ku punktowi, w którym dziś w zasadzie obejmuje już zupełnie wszystko, nie jest konsekwencją jego zgodności z naturą ludzką czy jakichś transhistorycznych praw natury, lecz wytworem jego własnych, historycznie określonych wewnętrznych praw ruchu. Te prawa ruchu zaś wymagały ogromnych przemian czy nawet wstrząsów społecznych, by zaczęły działać. Takie przemiany wymagały transformacji w metabolicznych procesach łączących człowieka z przyrodą. Przemian w formie zaspokajania podstawowych potrzeb życiowych społeczeństwa. 
Drugim istotnym wnioskiem jest to, że kapitalizm od początku był napędzany przez głęboko sprzeczne siły. Zastanówmy się jedynie nad najbardziej oczywistymi skutkami angielskiego kapitalizmu agrarnego. Z jednej strony nigdzie indziej nie istniały warunki dla materialnego dobrobytu podobne do tych we wczesnonowożytnej Anglii. Z drugiej strony jednak warunki te zostały osiagnięte kosztem powszechnego wywłaszczenia $i$ intensywnego wyzysku. Nie trzeba chyba dodawać, że te nowe warunki stanowiły również podstawę dla niespotykanych wcześniej i bardziej skutecznych form ekspansji kolonialnej i imperializmu, jak również tworzyły nowe pobudki i potrzeby dla takiej ekspansji - poszukiwanie nowych rynków i zasobów.

Są to efekty w całości wynikające z paradygmatu „ulepszania”: z jednej strony wydajność i zdolność do wykarmienia ogromnej populacji, a z drugiej podporządkowanie wszystkich innych celów imperatywowi zysku. W rzeczywistości oznaczało to, że ludzie, którzy mogliby być bez problemu wykarmieni, byli często skazani na głód. Istnieje zatem ogromna rozbieżność między zdolnościami wytwórczymi kapitalizmu i jakością życia, którą oferuje. Etyka „ulepszania” w swoim pierwotnym znaczeniu, a więc produkcji nierozłącznej z zyskiem, jest także etyką wyzysku, nędzy i bezdomności.

Etyka „ulepszania”, produktywności dla zysku, jest też oczywiście „etyką” nieodpowiedzialnego użytkowania ziemi, choroby „szalonych krów” i niszczenia środowiska. Kapitalizm zrodził się w samym stosunku człowieka z przyroda, na którym opiera się ludzkie życie. Transformacja tego fundamentalnego stosunku przez agrarny kapitalizm ujawniła wewnętrzne i nieprzypadkowe destruktywne dążenia systemu, przez które same podstawy istnienia poddawane są wymogom zysku. Innymi słowy, ujawniły prawdziwą tajemnicę, jaką skrywa kapitalizm.

Ekspansja kapitalistycznych imperatywów na całym świecie niesie ze sobą niektóre z efektów widocznych już w kraju ich narodzin. Proces wywłaszczenia, zanikania zwyczajowych praw własności, zmuszania do uznania imperatywów rynkowych i niszczenia środowiska postępuje. Proces ten zmienił swoją skalę od stosunków między wyzyskiwanymi a klasami wyzyskiwaczy do stosunków między krajami stosującymi imperialistyczna politykę a krajami od nich zależnymi. Ostatnimi czasy rozprzestrzenianie się imperatywów rynkowych przybrało na przykład postać przekonywania rolników w krajach Trzeciego Świata (przy pomocy takich międzynarodowych agencji kapitalistycznych jak Bank Światowy i Międzynarodowy Fundusz Walutowy) do zastapienia strategii samowystarczalności rolnej specjalizacją w uprawach nastawionych na zysk na rynku światowym. Opłakane skutki tych zmian zostaną zbadane $\mathrm{w}$ innym miejscu w tym numerze ${ }^{4}$.

\footnotetext{
${ }_{4}^{4}$ Mowa tu o Monthly Review 1998, 50 (3) (https:/ / monthlyreview.org/archives/1998/volume-50-issue-03-julyaugust-1998/).
} 
O ile destrukcyjne skutki kapitalizmu stale podlegają samoreprodukcji, o tyle nie można tego powiedzieć o jego pozytywnych efektach. Kapitalizm, który powstał w jednym kraju, zaczął narzucać swe imperatywy reszcie Europy, a ostatecznie całemu światu. Jego rozwój w innych rejonach globu nie mógł podążać dokładnie w tym samym kierunku. Zaistnienie pierwszego społeczeństwa kapitalistycznego przekształciło wszystkie inne. Późniejsza ekspansja kapitalistycznych imperatywów stale zmieniała warunki rozwoju gospodarczego.

Osiągnęliśmy punkt, w którym destrukcyjne skutki kapitalizmu daleko przekraczaja materialne korzyści. Na przykład żaden z krajów Trzeciego Świata nie może dzisiaj liczyć nawet na osiagnięcie naznaczonego sprzecznościami rozwoju, którego doświadczyła Anglia. Wraz z presją konkurencji, akumulacji i wyzysku, które są im narzucane przez bardziej rozwinięte systemy kapitalistyczne, próba osiagnięcia materialnej pomyślności na zasadach kapitalistycznych z coraz większym prawdopodobieństwem przyniesie jedynie negatywne aspekty kapitalistycznych sprzeczności - wywłaszczenie oraz wyniszczenie bez zapewnienia materialnych korzyści, a przynajmniej nie dla znakomitej większości.

Z doświadczeń angielskiego kapitalizmu agrarnego wynika również bardziej ogólna lekcja. Gdy już imperatywy rynku zaczną określać warunki reprodukcji społecznej, wszyscy aktorzy ekonomiczni - zarówno wyzyskiwacze, jak i producenci, nawet jeżeli zachowają własność środków produkcji, a nawet jej bezpośrednią formę - podlegają wymogom konkurencji, zwiększania produktywności, akumulacji kapitału oraz zintensyfikowanego wyzysku siły roboczej.

W związku z tym nawet brak wyraźnego podziału na wyzyskiwaczy i producentów nie stanowi gwarancji bezpieczeństwa (dlatego też „socjalizm rynkowy” to sprzeczność sama w sobie). Gdy rynek zostanie ustanowiony jako ekonomiczny mechanizm „dyscypliny” lub „regulator”, gdy aktorzy gospodarczy staną się zależni od rynku w kwestii warunków własnej reprodukcji, nawet pracownicy, którzy są właścicielami środków produkcji, posiadając je indywidualnie lub zbiorowo, będą zobowiązani do reagowania na imperatywy rynku. Zostaną zmuszeni do konkurencji i akumulacji, do postawienia pod ścianą innych „niekonkurencyjnych” przedsiębiorstw i ich pracowników i wreszcie do wyzysku samych siebie.

Historia kapitalizmu agrarnego i jej następstwa pouczają nas, należy to jasno stwierdzić, że gdziekolwiek imperatywy rynku reguluja gospodarkę i procesy reprodukcji społecznej, tam nie ma ucieczki przed wyzyskiem.

\section{Wykaz literatury}

Locke, John. 2015. Dwa traktaty o rzadzie. Tłum. Zbigniew Rau. Warszawa: Aletheia. 
Ellen Meiksins Wood (1942-2016) - była amerykańską historyczką marksistowską i teoretyczka. Wraz z Robertem Brennerem stworzyła nurt nazywany „marksizmem politycznym”. Autorka wielu książek między innymi The Retreat from Class (1986), za która otrzymała nagrodę im. Isaaca Deutschera, oraz wpływowej pracy The Origin of Capitalism (1999).

CYTOWANIE: Meiksins Wood, Ellen. 2017. Agrarne początki kapitalizmu. Praktyka Teoretyczna 4 (26): 343-360.

DOI: $10.14746 /$ prt.2017.4.13

AUTHOR: Ellen Meiksins Wood

TITLE: The Agrarian Origins of Capitalism

ABSTRACT: This article presents the underlying assumptions and main arguments of "political Marxism." The author shows how and why the beginning of capitalism should be primarily associated with the countryside and agriculture, and secondarily with the city and trade. The subordination of food production processes to the imperatives of capitalism determines capitalism's revolutionary character. The main reason for that lies in the transformation of the processes responsible for the reproduction of the whole society and not only for the distribution or redistribution of surpluses.

KEYWORDS: capitalism, Meiksins Wood, political Marxism, history, market 